\title{
Disability and Normalcy as Constructs in Doris Lessing's The Fifth Child
}

\author{
Shankar Subedi
}

\begin{abstract}
This paper aims to analyze Doris Lessing's The Fifth Child as story with a special focus on abnormal child Ben who is born with Down's syndrome and how society fear his difference and play an important role in constructing what is termed as disability. The young English couple, Harriet and David Lavatt move from a romanticized ideal to hazardous situations with the conception and birth of the fifth child, Ben who is described throughout the novel as an animal, an alien or a kind of monstrous baby or the baby of a monster. The disabled baby exercises an evil and destructive force upon the family. The novel ends with the formerly happy couple and family scattered across England and the family members have been physically and emotionally traumatized due to the birth of the abnormal baby 'Ben'. The mother's desire for a unconventionally large family is also a sign of abnormality. She refuses the social and class conventions that dictate small families. She also refuses medical technologies and interventions during conception and at birth. This serves to prove that concepts like normalcy and disability are socially constructed and can be challenged. For the purpose of theory the paper draws on the ideas related to normalcy and disability from The Disability Studies Reader edited by Lennard $J$ Davis.
\end{abstract}

Keywords: Disability, Normalcy, Social Construct, Conventions, Difference

\section{Introduction}

Lessing's novel The Fifth Child is the description of the couple David Lovatt and his wife Harriet and the eventful life after the birth of the fifth child who is born with a Down's Syndrome is more of a lump of flesh in the beginning. The lives of the couple and the whole family change for the worse as the baby is abnormal and society's attitudes towards the baby. The other members of the family see the child as a creature from another world and would like to avoid the baby. The child is seen as a sinister presence and has a baleful impact on the entire family and the other people in the neighbourhood. The baby's father David can't accept the baby and because of this a tension develops in his relation with his wife and the family is devastated by the ghostly presence of the abnormal child.

Not only the adults but also the children in the family and locality try their best to avoid the company of the abnormal child. They move away from the baby whenever it comes close to them and stare at him sideways with fear, hatred and suspicion. They don't like to play with him and single him out as the odd man out in their group. Even the dog in the family avoids the baby and moves towards the corner. The baby has his own ways of expressing himself and making himself

Visiting Lecturer of Saraswati Multiple Campus/Lecturer of Central Department of English University Campus, TU., Kirtipur, Nepal. 
understood to the people around him. He may not behave and respond to the external stimulus the way other kids do but it is the society that mistreats him and can't respect his difference.

Every human society has certain social values and assumptions and on the basis of those it constructs concepts like good and bad, moral and immoral, normal and abnormal and able and disabled. After creating these lines of demarcation, society discriminates the people whose physical and behavioral traits fail to meet the norms or the standards that society has created for dividing people with difference into different respectful and humiliating categories. The truth of such constructions is that the don't capture the realities of the so called abnormal and disabled people but highlight the attitudes of the people whose definitions can always be questioned and challenged to show that they are merely social constructs and can change with change in the attitudes and assumptions of the people who create and legitimize them.

How much David and Harriet are frightened by the birth of the abnormal child Ben is highlighted by the couple's fear while thinking about lovemaking. The baby was born despite the care they had taken to prevent unwanted things from happening. The following lines expose their fear:

But now they were both thinking, that creature arrived when we were being as careful as we know how - suppose another like him comes? For they both felt secretly, they were ashamed of the thoughts they had about Ben - that he had willed himself to be born, had invaded their ordinaries, which had no defenses against him or anything like him. (63)

The parents of the baby see him as an unwelcome presence in the family. They are so much afraid by the birth of the baby that every time they want have sex the think about the future babies that might be born deformed like the fifth one. A domain of life as lovemaking understood to be god's gift and a source of joy and freedom in human life is destroyed and defiled by their evil thoughts created by the birth of the baby. They think that the ordinary rhythm of their lives has been destroyed by the unwanted baby. How can parents entertain such shameful thoughts about their own children is very shocking and revealing about how people fear difference and creates false myths and notions about it.

The size of the family itself can be regarded as a sigh of abnormality if we look at it through the lens of normalcy as an outcome of socio-cultural construction. It is a very large family because there are so many people and children and look very anachronistic in modern times. Imagine such a family in modern England and think of how people in society would react to it. Some hundred years ago a family of this size would have been more or less acceptable but it is certainly an anomaly in present day British society. David and Harriet's children are enough for making people stare at the size. However, there is nothing inherently good or bad about having many children and a large family but cultural and financial situations of human beings are responsible for creating such attitudes towards people and object that tend to violate the existing norm.

\section{Theory and Textual Analysis}

Ben is born with Down's syndrome as the fifth child of David and Harriet but his birth into the family opens the Pandora's Box of trouble for the whole family. Ben is different from the other normal babies and cannot speak clearly as grows up and even when he speaks he has a thick voice and snarls. He just stares at objects and people which gives them a feeling a eeriness and the fear 
looking at him. He is strong and displays great energy in even the ordinary things he does. He once bit his own brother's arm and terrorized the family members and the other children. After the incident "No one felt like saying to the children, "Be careful of Ben" But there was no need after the incident with Paul's arm" (63) which is a proof that the baby instinctively beats and toys with other children but it does not happen intentionally and rationally. Right from the beginning Ben's parents have the premonition that he is going to be the cause of the destruction of the family because of his abnormality. "David and Harriet conferred in the low, almost guilty, incredulous voices that Ben seemed to impose. This baby was not six months old yet ... he was going to destroy their family life. He was already destroying it" (64). Ben's physical difference is taken with awe and contempt as well as doubt by his own parents let alone the other people what are not close to him and cannot understand him as much as his parents do.

Ben is born lime that and behaves in the way he does is not a fault of his. He is genetically formed like that and it is an automatic response that he comes up with when he responds to the external stimulus in his own unique way. However, it is the society that creates the idea of the norm and labels as abnormal whatever is different or deviates from the norm. For Foucault it is the "penetrating gaze" (16) of the doctor that creates the disease or abnormality. There is no necessity that a man must be born like another and should behave in the manner acceptable to the other normal people. For Lenard J. Davis:

To understand the disabled body, one must return to the concept of the norm, the normal body. So much of writing about disability has focused on the disabled person as the object of study, just as the study of race has focused on the person of color . . I do this because the 'problem' is not the person with disabilities; the problem is the way that normalcy is constructed to create the 'problem' of the disabled person. (5)

As Davis claims we can't understand the disabled body without first making sense of the norm on the basis of which disability is defined. Whatever fails to meet the requirements of the norm is socially rejected and is treated with fear, hatred and suspicion. This social construction is done with regard not only to deformed body but also on the basis of color, gender and caste and many other cultural and economic categories. In the novel the child Ben is the victim of such social discrimination and biased definition and conceptualization. The following lines from the novel show people view with suspicion and fear anybody born with some physical and psychological differences:

Heavy bars were put in, and there, Ben would stand on the sill, gripping the bars and shaking them, and surveying the outside world, letting out his thick raucous cries ... . sometimes a yell from Ben loud enough to reach downstairs silenced a conversation ... . Harriet knew that sometimes people went up to look up at Ben, out of the fearful, uneasy curiosity he evoked, when he was of the way. (65)

Frightened that Ben would harm other people and the children in the family, he is caged and put behind bars. He likes to move around freely and play in his own rough and wild manner but the family cannot give him the time and care he requires and silence him by putting him in a fixed place in order to control and manage him for their own convenience. This kind of behaviour stunts the physical as well as the mental growth of the child. People stop talking and a kind of silence rules the entire house when the sense that Ben is speaking and coming towards them. The child talks in his own way as is allowed by his structure but the other people expect him to talk 
the way an ordinary boy does. "One day, he talked. He did not say, "Mummy" or "Daddy", or his own name. He said "I want cake" ... The she told everyone, "Ben's talking. He is using sentences" (73). A child with his or her own differences should be respected as such and in the name of normal expectations we can't impose our own norms and rules on them. Actually the fault is not with such babies but we us who fail to take proper care of such children.

Normal people feel very awkward when the have to listen to the meaningless prattling of such children with differences. Disability is not actually a lack of ability but it denotes the ability to do things differently. Such people may not fit into the framework of our needs and expectations but must be allowed exist and act in their own way. His friends' response to how he speaks can serve as a good example of people's expectations. "The children were relieved he was talking normally. "Hello, Ben" one would say. "Hello", Ben replied, carefully handling back exactly what he had been given. "How are you, Ben?" Helen asked. "How are you?" he replied. "No" said Helen, "Now you must say, "I'm very well, thank you', or, "I'm fine" (73). The child's mother uses the word must which denotes it is normative and compulsory for the baby to talk in such a way that it will satisfy the expectations of the people who regard themselves as the custodians of the task of defining and demarcating what is normal and what is abnormal.

Society creates definitions of the normal and abnormal and set a standard or ideal to which people have to aspire. Those who fit into the ideal are respected and accepted socially and the ones who fail to meet the norm are rejected outright or are made the victims of social ostracism and stigmatization by the entire community. Davis's idea of the bell curve is very relevant here as "Any bell curve will always have as its extremities those characteristics of deviations or extremes. When we think of bodies in a society where the concept of the norm is operative, then people contrast to societies with the concept of which all people have a non deal status" (2).

According to Davis such norms are operative all human societies and the perceptions and behaviour of people are guided by such expectations and norm. Willy-nilly the people with deviations and deformities are forced to conform to the ideal or the standard failing which such people are treated as monsters or aliens from another world. The following lines from the novel shed light on this:

So, he (Ben) came out of his little prison and joined them downstairs. He seemed to know that he ought to be like them. He would stand, head lowered, watching how everyone talked and laughed... His face was on one face and then another: Whom even he was looking at became conscious of that insistent gaze and stopped talking; or turned a back, or a shoulder, so as not to have to see him. (66)

Ben wants to play with his siblings and comes downstairs to join them. He has been made to feel that he should try to look like them otherwise they would not regard as a member of their society. That he looks from one face to another is clearly his desire for social acceptance for which he has been struggling and becomes antisocial and the fear and avoid him. The don't like to play him and avoid his company as far as possible. They have learned this by observing the attitude of the adults towards Ben and will internalize it as they grow up. Let alone the idea of small children hating to be near him ,even his own father treats him as a creature who has just dropped from another planet and actually hates him. His dislike for the baby is so great that he tells his wife it is either him or they. "It's either him or us," said David to Harriot. He added, his voice full of cold dislike for Ben, "He's probably just dropped in from Mars. He's going back to report on what 
he's found down here. "He laughed-cruelly; it seemed to Harriot, who was silently taking in the fact" (79). It shows the father's secret desire to get rid of the baby and live life without any kind of disturbance. David's attitude to his own baby's disability is representative of how society in general perceives people with differences.

Many literary works present characters with disabilities and contrast them with other normal characters. Either the writers seem to collude with assumptions. It is an indication that the concept of normalcy and abnormality are so pervasive that there is no area of human endeavor or aspect of life that remains untouched and unaffected by the ideas of norms, standards and the ideals. For Davis:

My point is that a disabilities studies consciousness can alter the way we see just not novels that have main characters who are disabled but any novel. In thinking through the issue of disability, I have come to see that almost any literary work will have some reference to the abnormal, to disability, and so on. I would explain this phenomenon as the hegemony of normalcy. (Constructing 12)

Thus the idea of normalcy has penetrated all aspects of human life which is termed as the hegemony of the normalcy by the author. Even the mother of an abnormal child has to suffer so much humiliation and shame that she is made to feel like a criminal for bringing such a baby into this world. This applies to the feelings of Harriet in the novel, "Again, Harriet was wondering why she was always treated like a criminal. Ever since Ben was born it has been like this, she thought. Now it seemed to her the truth, that everyone had silently condemned her. I have suffered a misfortune, she told herself; I haven't committed a crime" (83). It is not the fault of the mother that a disabled child is born to her. She may have done something wrong unknowingly but no mother does something like that deliberately. How callous society can become is shown by the attitude of her own husband and her relatives after the birth of Ben.

When we study literature we find texts that present the protagonist as a norm or the standard that other characters in the book have to emulate. For Davis, “. . . the very structures on which the novel rests tend to be normative, ideologically emphasizing the universal quality of the central character whose normativity encourages as identifying with him or her" (11). For Lynn Rose, "Deafness was indeed a curse ... Deprivation of hearing . . it meant a deprivation of verbal communication and perceived intelligence, meant separation from the political and intellectual arena. A curse of deafness was appropriate not only for one's political opponents ..." (Deaf and Dumb 21). In ancient Greece deafness was treated as a means for subjugating and disempowering an individual and was kept away from the domains of active public life like politics and social service. For James I. Charlton,

The dehumanization of people with disabilities through language (as just one obvious example) has a profound influence on consciousness . . . are constantly told by the dominant culture what they cannot do and what their place is in society . . . is not hard to comprehend when we consider all the ideological powers at work. (The Dimensions of Disability oppression 225)

Ideology of the norm and the various forms of power existing in society play a pivotal role in dehumanizing the people with differences. 
The story of Ben's difference told within the world of the novel is constantly disbelieved by the other characters in the novel. From the very beginning, Harriet's narration of Ben's story of difference to doctors, neighbors and the other members of her family is met with suspicion. Other characters understand her narrative of difference to be indicative of her own difference rather than her son's. Even the psychiatrist sees that the problem is not with the baby but with the mother. Ben is seen by other people as funny or hyperactive which is a clear indication of the fact about how society treats people with physical or emotional difference. Society exaggerates the reality of Ben's difference and presents it as a kind of deviation or abnormality. Even though she is ambivalent to the physical condition of her baby for Norma Rowen, "Harriet's care for her child is movingly demonstrated throughout the book" (Frankenstein Revisited, 7). However, Harriet also feels that the baby is a burden and getting rid of it would mean a kind of freedom and a great release from stress.

Disability is a construct is and the problem can be located not with the people with disability but with the people who misconceptions about disability. Harriet once takes her child to a doctor for whom, "the problem is not with Ben with you. You don't like him very much" (109). In The Fifth Child we see different kinds of fears at work. Harriet herself is responsible to some degree for how her baby is treated by the society. At some level of her heart, she doesn't seem to like her child. She doesn't bring herself to fully accepting the abnormality of her own baby. But on the other hand, she chooses to keep the baby to the displeasure of herself and many other people. She also decides to rescue the baby from the institution and give him motherly care and it shows her determination not to accept the disability of the baby. She saves the baby from the cruel clutches of the social institutions and the authorities and proves that she will accept social rejection but will accept the baby. She tries to prove that normalcy is a construct and is going to have the baby with her.

The novel is both a story of a mother and as well as a horror story .The very presence of the baby in the family inspires fear in his siblings and parents. The members of the family also avoid the baby and go away from home when the baby is around. It is because of these kinds of responses from his own people that Ben is maddened by their behaviour and treatment of him. For Lynn Sukenick, "Lessing takes her hero on a journey away from the customary responsibilities of his social role and into schizophrenia" (17). As Ben grows up he joins a gang of social misfits and has great difficulty socializing and drifts away from family and society which can be read as a consequence of how he had been mistreated and ostracized by society.

\section{Conclusion}

The novel The Fifth Child is the story of the fifth child Ben who is born with Down's Syndrome and the kind of social rejection he suffers into the hands of his own parents and the other members of the family. He has physical and mental differences but has his own ways of complaining, weeping and expressing his anger and disgust. His abnormality is less inherent in his body and has more to do with the attitude of the people who abhor and avoid him because of his differences. The novel portrays the loneliness and frustration of Ben and his mother who is treated as a criminal for giving birth to such a baby. He is avoided in play by his own friends and is seen with a kind of awful dread as if he is a throwback to an earlier age and is an alien from another world. His own father is shocked and horrified by the birth of the baby and quarrels with his own 
wife over the abnormality of the child. The social institution where he is admitted mistreats him and suffers like an animal there. People with disability are not devoid of ability but can act and respond to the external stimuli in their own unique ways. Society sets some standards and norms and expects everyone to conform to. These concepts are not natural categories but social constructs.

\section{Works Cited}

Charlton, James I. "The Dimension of Disability Oppression.” The Disability Studies Reader. Routledge, 1975, pp. 217-231.

Clark, Emily. Re-reading Horror Stories: Maternity, Disability and Normative in Doris Lessing's "The Fifth Child." Feminist Review, 2011, No. 98, pp. 173 - 189.

David, Lennard J.( Ed). "Constructing Normalcy.” The Disability Studies Reader. Routledge, 1975, pp. 3-17.

Foucault, Michel. The Birth of the Clinic: An Archaeology of Medical Perception. Vintage, 1975.

Lessing, Doris. The Fifth Child. Jonathan Cape, 1988.

Lynn M. Rose. "Deaf and Dumb in Ancient Greece." The Disability Studies Reader. Routledge, 1975, pp. 17-33.

Norma, Rowen. Frankenstein Revisited: Doris Lessing's "The Fifth Child." Journal of the Fantastic in the Arts, Vol. 2, No.3 (7) Special Issue 1990, pp. 41-49.

Sukenick, Lynn. "Feeling and Reason in Doris Lessing's Fiction." Contemporary Literature, Autumn, 1973, Vol.14, No.4, pp. 515-535. 